\title{
Water Quality Assessment in Terms of Water Quality Index (WQI): Case Study; Gorganroud River, Golestan Province, Iran
}

\author{
Elham Mirrasooli ${ }^{*}$, Rasoul Ghorbani' ${ }^{1}$, Masoud Molaei ${ }^{2}$ \\ ${ }^{1}$ Department of Fisheries, Gorgan University of Agricultural Sciences and Natural Resources, Gorgan, Iran \\ ${ }^{2}$ Department of Fisheries and Environmental Science, Gonbad University of Agricultural Sciences and Natural Resources, \\ Gonbad, Iran \\ Email: *elhammirrasooli@gmail.com
}

How to cite this paper: Mirrasooli, E., Ghorbani, R. and Molaei, M. (2017) Water Quality Assessment in Terms of Water Quality Index (WQI): Case Study; Gorganroud River, Golestan Province, Iran. Open Journal of Ecology, 7, 640-649. https://doi.org/10.4236/oje.2017.713044

Received: October 11, 2017

Accepted: December 18, 2017

Published: December 21, 2017

Copyright $\odot 2017$ by authors and Scientific Research Publishing Inc. This work is licensed under the Creative Commons Attribution International License (CC BY 4.0).

http://creativecommons.org/licenses/by/4.0/

\begin{abstract}
The most important aquatic ecosystems are freshwater rivers, which are considered as biodiversity and drinking water. In this regard, the quantitative and qualitative study of these resources is an important pillar of sustainable development. Gorganroud is one of the most important rivers in northeastern Iran; therefore the aim of this study was to study survey of Gorgnroud River water quality in Golestan Province using Water Quality Index (WQI). For this purpose, five sampling stations were selected along the Gorgnroud River, and samples were taken from April to August of 2015 every 45 days at sampling stations. The parameters of dissolved oxygen, nitrate, nitrite and $\mathrm{PH}$ were measured at each turn and the data were analyzed by WQI qualitative index. The results showed that the Water Quality Index at the first station (91/22); at the second station (85/51); at the third station (89.30); at the fourth station $(87 / 14)$ and fifth station (81/11). The water quality index indicates that water quality of the Gorgnroud River was in a very good quality class during the spring and summer seasons.
\end{abstract}

\section{Keywords}

Water Quality Index, Gorgnroud River, Physical and Chemical Parameters

\section{Introduction}

Water is a vital resource for any biological and human phenomenon and is one of the most important and fundamental sources for developing countries, those countries without any long-term plan regarding this specific source will not be able to enjoy more development and progress [12]. It should be mentioned that 
any change in the level of economic and financial development of a country has direct and indirect effect on the well-being of individuals who are living in that country, so evaluating these resources is really crucial [1] [2]. Safe water is one of the essential requirements for the life of human beings, which requires quality control by means of laboratory tests and different indices for controlling it [3]. A small part of the water resource is about one percent including surface water, current, wetlands and lakes that can be exploited and used directly by humans. So reducing the quality of current water, such as rivers and streams that are heavily influenced by humans, is one of the current concerns [4]. One of the most widely used and simple methods for measuring surface water quality is the use of water quality indicators [5]. Due to the entry of various pollutants into aquatic ecosystems which, in addition to ecological values, are also of high economic importance, their health value is of great importance [6]. The most important aquatic ecosystems are freshwater rivers, which are considered as biodiversity and drinking water. In this regard, the quantitative and qualitative study of these resources is an important pillar of sustainable development [7]. Quantitative and qualitative changes in physical and chemical properties of water indicate the presence of contamination in ecosystems [8] and since our country is facing limited water resources and is considered a low-water country, it is inevitable to know the quality of available water resources for their proper management [9]. Therefore, it can generally be stated that due to the increased utilization of river surface resources and the reduction of the flow due to reduced rainfall, climate change and increased pollution, Assessment of river health in different regions of the country and knowledge of the quality of water resources in conservation, planning and management of these resources is very important and from where that The WQI Water Quality Index is an attempt to provide a general response to water quality. Therefore, the purpose of this study is to evaluate the ecological health of Gorgnroud River in Golestan province using the WQI index. Essentially the WQI is calculated by comparing the water quality data to "Guidelines for Canadian Drinking Water Quality". The WQI measures the scope, frequency, and amplitude of water quality exceedances and then combines the three measures into one score. This calculation produces a score between 0 and 100 . The higher the score, the better the quality of water. The scores are then ranked into one of the five categories described below:

Excellent: (WQI Value 95 - 100)-Water quality is protected with a virtual absence of impairment; conditions are very close to pristine levels

Very Good: (WQI Value 89 - 94)-Water quality is protected with a slight presence of impairment; conditions are close to pristine levels.

Good: (CWQI Value 80 - 88)-Water quality is protected with only a minor degree of impairment; conditions rarely depart from desirable levels.

Fair: (WQI Value 65 - 79)-Water quality is usually protected but occasionally impaired; conditions sometimes depart from desirable levels.

Marginal: (WQI Value 45 - 64)-Water quality is frequently impaired; conditions often depart from desirable levels. 
Poor: (WQI Value 0 - 44) - Water quality is almost always impaired; conditions usually depart from desirable levels [10]

For Assessment of the health status of the Ziarat Stream based on NSFWQI (National Sanitation Foundation Water Quality Index) quality index (Golestan Province) and Samples were taken from 10 hydrometer stations (in spring and summer 2012) along the Ziarat Stream. At each sampling, DO (Dissolved Oxygen), $\mathrm{pH}$ (potential of hydrogen), $\mathrm{BOD}_{5}$ (Biochemical oxygen demand), $\mathrm{NH}_{3}$ (Ammonia), $\mathrm{NO}_{3}$ (Nitrate), $\mathrm{PO}_{4}$ (phosphate), Water temperature, turbidity and Fecalcoli quality was measured. The data were analyzed by NSFWQI quality index. The result showed that the best situation was related to the first station in the June month and the worst situation was related to 5 stations in April. As for the present results quality condition of Ziarat, Straem was unsuitable and the decision-making process for reducing the pollutant of the Zyarat watershed can be facilitated by taking into consideration the results of this research given the time/budget constraints [3]. Karbasi and Also Compilation of Water Quality Index for River Quality Assessment (Case Study of Gorgan Rood River) and the result showed in the qualitative water index, the fossil foliar coliform and biochemical oxygen demand parameters increased compared to the NSF index [11]. Dadolahi and Arjomand (2011) an article titled Water quality index of Karoon River as indicator of Khorramshahr Soap Factory sewage effects and The comparison of physic-chemical parameters of water and sewage with the standard values defined by Department of Environment, showed that the amount of COD, BOD, and Chlorine (means 1300, 169.8 and 4042.9 ppm, respectively) in sewage is higher than the standard level. Based on water quality index, stations 1 , 2,3 and factory sewage with an annual quality index of 54.63, 40.29, 45.71 and 24.32 were classified as moderate, bad and very bad, respectively. There was a significant difference $(\mathrm{p}<0.05)$ in factors such as BOD, COD, nitrate, phosphate, and bicarbonate among the stations during the sampling period. The results also revealed factory sewage has affected the river water quality in spite of high water volume and sewage exit flow. These changes in the quality of river water indicate an increase of many parameters in second station and decrease in the third station which shows Karoon River high ability of self-purification [12].

\section{Materials and Methods}

\subsection{Describing the Area under Study}

Gorganroud is one of the most important rivers in northeastern Iran. This river originates from the Aladagh Mountain range in Bojnourd City and after passing $250 \mathrm{~km}$ of Turkmen Sahra cluster areas; it flows into the plain of Gorgan and flows from Khwaja Nafs area near the Turkmen port to the Caspian Sea. The total area of the Gorgan River basin is $1,019,700$ hectares, $41 \%$ of which is forestland and $20 \%$ of the pastures, and $39 \%$ of it is agricultural land, where cultivars are cultivated annually [13]. The longitude between $54^{\circ} 3^{\prime \prime}$ to $56^{\circ} 13^{\prime \prime}$. Eastern latitude and $37^{\circ} 45^{\prime \prime}$ to $36^{\circ} 23^{\prime \prime}$. North latitude are located in Golestan province. 
Table 1. Geographic coordinates of sampling stations in Gorganroud river survey.

\begin{tabular}{lcc}
\hline & \multicolumn{2}{c}{ Geographical coordinates } \\
\cline { 2 - 3 } & $\mathrm{N}$ & $\mathrm{E}$ \\
\hline 1. (Sourced) & 28.36 & 51.52 \\
2. (Before Golestan Dam) & 34.37 & 55.49 \\
3. (After Golestan Dam) & 17.37 & 55.18 \\
4. (Aq Qala) & 28.36 & 52.51 \\
5. (Khaje Nafas) & 14.36 & 52.35 \\
\hline
\end{tabular}

Geographic coordinates of sampling stations in Gorganroud river survey showed in Table 1.

\subsection{Sampling Procedures}

In this study, five sampling stations were selected and sampling took place from April to August 2015 every 45 days (According to the sampling of water resources of the Water and Wastewater Company of Iran, which can be done monthly for sampling 45 days) and samples were taken in duplicate at the same hour of the day throughout the study. Sampling stations along the river route were determined based on factors such as the location of the settlements, industrial areas, access roads, altitudes, slopes, bedding, water flow rate and land use type of marginal land. In this study physiochemical characteristics and nutrients of water, including $\mathrm{DO}(\mathrm{mg} / \mathrm{L})$ and $\mathrm{pH}(\mathrm{mg} / \mathrm{L})$ With Photometric portable device (Model Wagtech Photometer 7100) and nitrate and nitrite (mg/l) were measured using a spectrophotometer in the laboratory.

\subsection{Analytical Methods}

Data were analyzed by WQI quality index and spss21 software was used to determine the data normality and correlation coefficient between parameters.

\subsection{Calculating WQI Indicator}

To calculate this index, 4 parameters including nitrate, nitrite, dissolved oxygen, and ph were used. Then the required values for calculating the index were calculated based on the following relationships [14].

$$
\mathrm{RW}=\mathrm{AW} / \sum \mathrm{AW}
$$

$\mathrm{RW}_{1}=$ Weight ratio of each parameter (Table 2)

$\mathrm{AW}_{2}=$ is the weight assigned to each parameter, which is based on expert opinion in previous studies (Table 2) [15].

$$
\begin{gathered}
\mathrm{Qi}=(\mathrm{Ci} / \mathrm{Si}) * 700 \\
\mathrm{Qi}=(\mathrm{Ci}-\mathrm{Vi} / \mathrm{Si}-\mathrm{Vi}) * 700
\end{gathered}
$$

In Equations ((2) and (3)): Qi: the quality level; Ci: the amount obtained from each parameter in the laboratory; Si: The amount reported in the global drinking 
Table 2. Weight assigned to each parameter in different sources and their mean [16].

\begin{tabular}{ccccc}
\hline Researcher & $\mathrm{PH}$ & $\mathrm{DO}(\mathrm{mg} / \mathrm{l})$ & $\mathrm{NO}_{3}(\mathrm{mg} / \mathrm{l})$ & $\mathrm{NO}_{2}(\mathrm{mg} / \mathrm{l})$ \\
\hline Abrahão et al., 2007 & 1 & 4 & 2 & 2 \\
Boyacioglu, 2007 & 1 & 4 & 3 & \\
Chougule et al., 2009 & 4 & 4 & & \\
Dwivedi and Pathak, 2007 & 4 & 4 & & 2 \\
Kannel et al., 2007 & 1 & 4 & 2 & 2 \\
Karakaya and Evrendilek, 2009 & 1 & 4 & 2 & 2 \\
Pathak and Banerjee, 1992 & 4 & 4 & & 2 \\
Pesce and Wunderlin, 2000 & 1 & 4 & 2 & $2 / 2$ \\
Mean & $2 / 1$ & 4 & & 2 \\
\hline
\end{tabular}

Table 3. The weight ratio of water quality parameters [16].

\begin{tabular}{cccc}
\hline Parameters & RW & AW & Standard drinking water WHO. 2004 \\
\hline $\mathrm{NO}_{2}(\mathrm{mg} / \mathrm{l})$ & $0 / 141,844$ & 2 & 30 \\
$\mathrm{NO}_{3}(\mathrm{mg} / \mathrm{l})$ & $0 / 156,028$ & 2.2 & 50 \\
$\mathrm{DO}(\mathrm{mg} / \mathrm{l})$ & $0 / 283,688$ & 4 & 5 \\
$\mathrm{pH}$ & $0 / 148,643$ & 2.1 & $6 / 5-8 / 5$ \\
\hline
\end{tabular}

Table 4. Qualitative classification of natural waters based on the overall score of the WQI index [10] [17].

\begin{tabular}{cc}
\hline Qualitative class & The value of the obtained index \\
\hline Poor & $0-44$ \\
Marginal & $45-64$ \\
Fiar & $65-79$ \\
Good & $80-88$ \\
Very Good & $89-94$ \\
Excellent & $95-100$ \\
\hline
\end{tabular}

water standard, Vi: The optimal value for $\mathrm{Ph}$. is 7 and for DO it is equal to 14/6. The weight assigned to each parameter and mean used is given in Table 3.

Finally, to calculate the Water Quality Index (WQI), the SLI (is the sub-index of with parameter) subcategory was first calculated for each parameter (Equation (4)) and from the total SLIs, the numerical value of WQI was estimated (Equation (5)).

$$
\begin{gathered}
\mathrm{SI}=\mathrm{RW} * \mathrm{Qi} \\
\mathrm{WQI}=\sum \mathrm{WiQi}
\end{gathered}
$$

Using Equation (5), the Water Quality Index (WQI) was calculated at different stations and sampling stages. Finally, the water quality status at stations and different sampling stages was determined based on the general classification of WQI water quality index (Table 4). 


\section{Results}

The results of measuring the physicochemical parameters of water at different sampling stations are given in Table 5 .

Significant differences were observed in some of the measured parameters between different sampling stations $(\mathrm{P}<0.05)$. Water Quality Index (WQI) was calculated using 4 parameters of nitrite, nitrate, dissolved oxygen, and phage. In the interpretation of the results of this index, it is assumed that with increasing pollution, the WQI quality index also increases, which indicates an increase in pollution and a decrease in water quality. Based on the findings of the 5 sampling stations, it can be stated that the numerical value of the quality index The WQI did not make a significant difference between the sampling stations. The maximum WQI quality index at station 1 was 91/22 and the minimum amount was at station 5 with $81 / 11$. The observed differences in the qualitative index between the sampling stations are quantitative and statistical and are within range (80 - 94) and are not excluded from this range, indicating that sampling stations during the time of the present research it has a good quality (Table 6 and Figure 1).

Table 5. Parameters measured at sampling stations (mean \pm SD).

\begin{tabular}{ccccc}
\hline Stations & $\mathrm{NO}_{2}(\mathrm{mg} / \mathrm{l})$ & $\mathrm{NO}_{3}(\mathrm{mg} / \mathrm{l})$ & $\mathrm{DO}(\mathrm{mg} / \mathrm{l})$ & $\mathrm{pH}$ \\
\hline 1 & $0.09 \pm 0.01^{\mathrm{a}}$ & $8.65 \pm 1.18^{\mathrm{a}}$ & $5.12 \pm 1.11$ & $7.3 \pm 0.08$ \\
2 & $0.08 \pm 00.0^{\mathrm{b}}$ & $9.55 \pm 1.06^{\mathrm{ab}}$ & $6.81 \pm 1.6$ & $8.53 \pm 0.08$ \\
3 & $0.08 \pm 0.00^{\mathrm{b}}$ & $12.44 \pm 1.02^{\mathrm{ab}}$ & $8 \pm 8.18$ & $7.11 \pm 0.03$ \\
4 & $0.08 \pm 0.00^{\mathrm{b}}$ & $10.47 \pm 1.04^{\mathrm{ab}}$ & $9.78 \pm 1.6$ & $7 \pm 0.07$ \\
5 & $0.08 \pm 0.00^{\mathrm{b}}$ & $20.62 \pm 4.05^{\mathrm{b}}$ & $8.73 \pm 1.17$ & $7.41 \pm 0.04$ \\
Average & 0.08 & 12.34 & 7.68 & 7.47 \\
\hline
\end{tabular}

Table 6. WQI index values calculated at different sampling stations (mean \pm SD), There was no significant difference in WQI water quality index between sampling stations $(\mathrm{P}>$ 0/05).

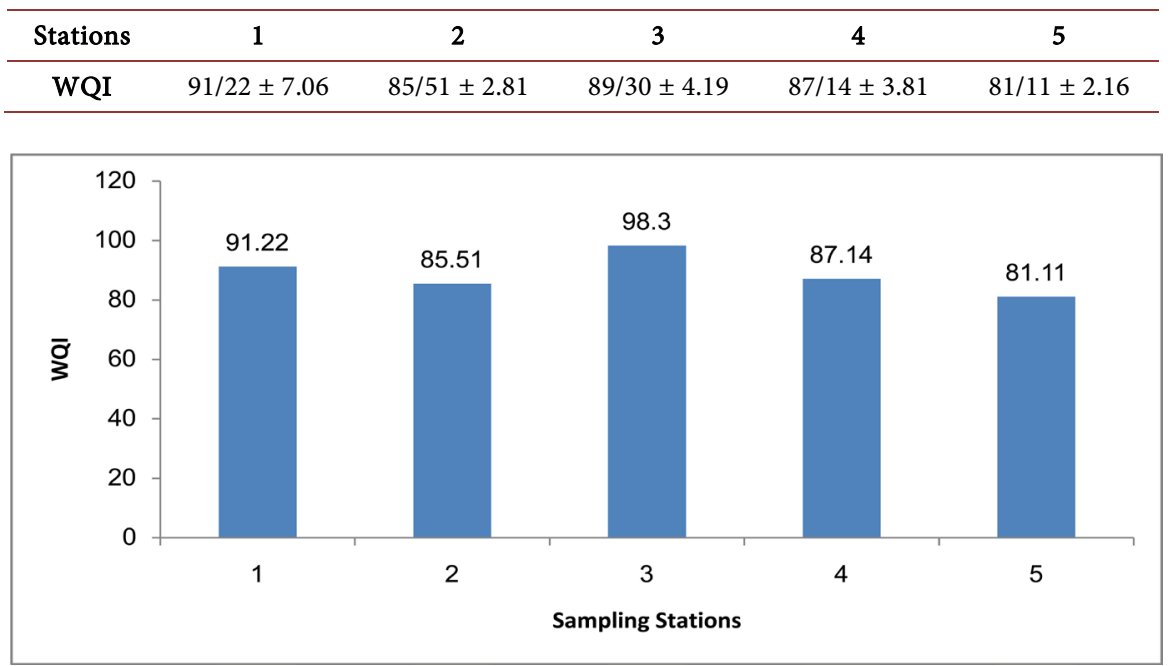

Figure 1. Average WQI water quality index at the stations studied. 
In general, it can be stated that according to the results obtained, the water quality of the Gorgnroud River in the province of Golestan is in poor class in terms of time and is unsuitable for human consumption.

\section{Discussion and Conclusion}

Based on the findings of the present study, there was a significant difference in the nitrate level of the Gorganroud River in Golestan province at different stations. The average amount of nitrate in the river water was $12.34 \mathrm{mg} / \mathrm{L}$, which was reported as the amount of nitrate in surface water based on available resources and environmental standards were $1 \mathrm{mg} / \mathrm{l}$ [18]; more it has been the standard of the environment. It can be stated that the causes of nitrate entry into the river water are human activities around the river and the influence of waste water on agriculture and home [12]. On the other hand, the nitrite content of the Gorganroud River in Golestan province was significant at the station and the mean nitrite in the river water was equal to $0 / 08 \mathrm{mg} / \mathrm{L}$. Considering that the amount of nitrite in surface water based on available resources and environmental standards should not be higher than $0.51 \mathrm{mg} / \mathrm{L}$ is reported $(\mathrm{EPA}, 1994)$ in the environmental standard have been. In confirmation of these results, it can be noted that Kazhi et al. (2009) [19] reported nitrate, nitrite, phosphate and ammonium nitrate levels in Lake Manchar, Pakistan, due to the influence of domestic wastewater and fertilizers used in the agricultural sector. Lodh et al. in 2014, [20] on the Indian Ocean Lake Anset, nitrate was considered as the main nutrient for the growth of algae and phytoplankton, and its concentration could be affected by the fluctuation of plankton. The $\mathrm{pH}$ measured during the sampling time at the station was an average of 7.47 , located in the alkaline range. This factor plays a significant role in the health and fertility of water and plays an important role in assessing water quality. The mean phage in the stations studied in this study conformed to the standards of Iran and the world. It is worth noting, however, that the $\mathrm{PH}$ of the ecosystems is due to the geological and hydrological properties of the watersheds; the input of acidic substances and the level of lake fertility. The dissolved oxygen content at all stations was 7.68 on average, with a maximum at station 4 and a minimum amount at station 1 . The amount of dissolved oxygen depends on factors such as water temperature (with increasing water temperature, reduced oxygen dissolution), vital activities such as respiration and organic matter decomposition (increasing vital activity of reducing oxygen dissolution). The effect of oxygen on water quality is very influential and can have a significant effect on its color, taste, and smell. The results of the changes in dissolved oxygen are consistent with the results of Gajendra et al. [21] in 2014. The results showed that water quality of the Gorganrud River, despite the decrease in spring and summer, was in poor condition (between 100 - 200). Khalaji et al., in 2017 [16], evaluated the water quality of Lake Zayandehrood dam using the WQI index and the sign they said that water quality is in good condition and that care should be taken to maintain water quality. 
Amin Pourshiani et al. (2016) [22] evaluated the water quality of Gharbroodbar River using the NSFWQI qualitative index and Liou pollution index. According to the results of this study, the monthly average of the NSFWQI index is in the range of 50 - 50 and the monthly average of Liou index ranges from 1.1 to 3.85. Based on these indices, the No. 1 station was of the best quality and the No. 4 station had the worst quality. According to the NSFWQI index, Rudbar gas is ranked in the middle class (70 - 50) and based on the Liou index in a slightly polluted class (2 - 3) (Salari et al. (2013) [23] Quantitative and Qualitative Assessment of Karoon River Water Using NSFWQI Index and AHP Method). Subsequently, the nine present NSF parameters' weights have been changed and modified using the analytical hierarchy process (AHP) method as well as experts' opinions in the field in a way to satisfy local conditions Yan et al. (2016) [7] Ecosystem health assessment of the Liao River Basin upstream region is based on ecosystem services and the result showed there were significant spatial differences in ecosystem health in this region. In general, the west regions were better than the east, ecosystem health of regions in descending order is as follows: Laoha River sub-basin NXiliao River sub-basin, and Xila Mulun River sub-basin $\mathrm{N}$ Xinkai River sub-basin. Moreover, improvements in ecosystem health were greater in the mainstream sub-basins than in the branch sub-basins. Thus, the eastern regions are key areas for ecosystem health conservation, and ecosystem service is the principal constraint for local ecosystem health. Generally, based on the results obtained, it can be stated that the qualitative conditions of the passage of undesirable pilgrimage were introduced. In general, it can be said that according to the results of the present research and their comparison with the water quality standards in Iran and the world, water of the Gorganrud River of Golestan province during the period of this research was in terms of quality in poor and has not capacity of being used for human consumption. However, due to the changes in the WQI index and the beginning of its exit from the good quality waters, the river's water volume in summer is reduced and uncooperative land use changes in the watershed, etc. Precise and continuous assessments of water quality in this river are necessary.

\section{References}

[1] Çiftçioğlu, S. and Almasifard, M. (2015) The Response of Consumption to Alternative Measures of Financial Development and Real Interest Rate in a Sample of Central and East European Countries. Journal of Economics, 3, 1-6. https://doi.org/10.15640/jeds.v3n2a1

[2] Almasifard, M. (2013) An Econometric Analysis of Financial Development's Effects on the Share of Final Consumption Expenditure in Gross Domestic Product. Master's Thesis, Eastern Mediterranean University (EMU)-Doğu Akdeniz Üniversitesi (DAÜ).

[3] Ghorbani, R., Hajimoradlou, A., Molayi, M., Naeimi, A., Norozi, N. and Vesaghi, M. (2015) Assessment of the Health Status of the Ziyarat Stream Based on NSFWQI Quality Index (Golestan Province). 4, 111-122.

[4] Sadeghi, M., Bay, A., Bay, N., Soflaie, N., Mehdinejad, M. and Mallah, M. (2015) 
The Survey of Zarin-Gol River Water Quality in Golestan Province Using NSF-WQI and IRWQISC. Journal of Health in the Field, 3, No. 3.

[5] Pinto, U., Maheshwari, B., Sherestha, S. and Morris, C. (2012) Understanding the Meaning of River Health for a Community: Perspectives from the Peri-Urban Region of the Hawkesbury-Nepean Catchment, Australia. Water Policy, 14, 766-783. https://doi.org/10.2166/wp.2012.074

[6] Park, Y. and Hwang, S. (2016) Ecological Monitoring, Assessment, and Management in Freshwater Systems. Water, 8, 324. https://doi.org/10.3390/w8080324

[7] Yan, Y., Zhao, C.L., Wang, C.X., Peng, S., Zhang, Y.J. and Wu, G. (2016) Ecosystem Health Assessment of the Liao River Basin Upstream Region Based on Ecosystem Services. Acta Ecologica Sinica, 36, 294-300. https://doi.org/10.1016/j.chnaes.2016.06.005

[8] Asiabi-Hir, R., Mostafazadeh, R., Raoof, M. and Esmali-Ouri, A. (2016) Water Poverty Index and Its Importance in Water Resources Management. Extension and Development of Watershed Management, 3, 17-22.

[9] Sharifinia, M. (2012) Benthic Macroinvertebrate Distribution in Tajan River Using Canonical Correspondence Analysis. Caspian Journal of Environmental Sciences, 10, 181-194.

[10] CCME (2001) Canadian Water Quality Guidelines for the Protection of Aquatic Life: Canadian Water Quality Index 1.0 Technical Report. Canadian Environmental Quality Guidelines, Winnipeg.

[11] Karbasi, A. and Mirmohammadhosseini, F. (2012) Water Quality Index Development for Assessing the Water Quality of Rivers. Case Study of Gorgan Rood River, First National Conference on Flow and Pollution, Tehran, Tehran University, Water Institute.

[12] Dadolahi-Sohrab, A. and Arjomand, F. (2011) Water Quality Index of Karoon River as an Indicator of Khorramshahr Soap Factory Sewage Effects. JOC, 1, 21-27.

[13] Bagheri, H., Sharammad, T., Kheirabadi, V., Darvish Bastami, K. and Bagheri, Z. (2012) Measurement and Evaluation of Heavy Metal Contamination in Sediments of Gorgan Rood River. Journal of Oceanography, 5, 35-39.

[14] Brown, R.M., McClellan, N.I., Deininger, R.A. and Tozer, R.G. (1970) A Water Quality Index-Do We Dare? Water Sew Works, 117, 339-343.

[15] Fathi, P. (2013) Assessment of Water Quality in Choghakhor Wetland by Using Large Bulk Fertilizers. Master's End, 80 p.

[16] Khalaji, M., Ebrahimi, E., Motaghe, E., Asadola, S. and Hashemenejad, H. (2017) Water Quality Assessment of the Zayandehroud Lake Using WQI Index. ISFJ, 25, 51-63.

[17] Ramakrishnaiah, C.R., Sadashivaiah, C. and Ranganna, G. (2009) Monitoring of Aquatic Macroinvertebrates as Bioindicator for Assessing the Health of Wetlands. Ecological Indicators, 9, 118-128. https://doi.org/10.1016/j.ecolind.2008.02.004

[18] EPA (1996) Quality Criteria for Waters. Washington DC.

[19] Kazi, T.G., Arain, M.B., Jamali, M.K.,Jalbani, N., Afridi, I., Sarfraz, R.A., Baig, J.A. and Shah, A.Q. (2009) Assessment of Water Quality of Polluted Mlake Using Multivariate Statistical Techniques: A Case Study. Ecotoxicology and Environmental Safety, 72, 301-309. https://doi.org/10.1016/j.ecoenv.2008.02.024

[20] Lodh, R., Paul, R., Kurmakar, B. and Das, M.K. (2014) Physicochemical Studies of Water Quality with Special Reference to Ancient Lakes of Udaipur City, Tripura, India. International Journal of Scientific and Research Publication, 42, 2250-2315. 
[21] Gajendra, R., Swapnaja, S. and Smita, M. (2014) Monthly Variation of Physicochemical and Microbiological Characteristics of Sambhaji Lake Solapur, Maharashtra. Advances in Applied Science Research, 5, 149-152.

[22] Amin Pourshiani, S., Mohammadi, M., Khalidian, M. and Mirroshandel, A. (2016) Evaluation of Water Quality in Gharroodbar River Using the Qualitative Index of NSFWQI and Liou Infection Index. Ph.D. Dissertation, Pivot Eco-Biology. 8. Number 27, 65-78.

[23] Salari, M., Radmanesh, F. and Heidar Zarei, M. (2013) Quantitative and Qualitative Assessment of Karoon River Water Using NSFWQI Index and AHP Method. $\mathrm{Hu}^{-}$ man and Environmental Journal, 10, 13-22. 